\title{
Biological Stereoselective Reduction of 4-tert-Butylcyclohexanone by Anthracnose Fungi
}

\author{
Shigeaki OKamura, Mitsuo MiYazawa, and Hiromu KameOKa \\ Department of Applied Chemistry, Faculty of Science and Engineering, Kinki University \\ (3-4-1, Kowakae, Higashiosaka-shi, Osaka 577-8502)
}

\begin{abstract}
The biotransformation of 4-tert-butylcyclohexanone was conducted using ten anthracnose fungi as biocatalysts. The 4-tert-butylcyclohexanone was reduced to the corresponding cis- and transalcohols. The biotransformation of 4-tert-butylcyclohexanone resulted mainly in its transformation to trans-4-alcohol, using Colletotrichum lagenarium, C. atramentarium MAFF 712102, C. fragariae, $C$. graminicola MAFF 305460, C. lindemuthianum(C-3) and C. lindemuthianum(C-13). The cis- and transalcohol products were obtained at a ratio of $1.0: 6.0$ with stereoselectivity by Colletotrichum lagenarium after 7 days incubation. The cis-alcohol was formed with stereoselectivity by Glomerella cingulata, C. lindemuthianum(C-1), C. trifolii MAFF 305389 and C. dematium MAFF 410046.
\end{abstract}

Key words : biotransformation, 4-tert-butylcyclohexanone, biological stereoselective reduction, anthracnose fungi

\section{Introduction}

We have investigated the microbial transformation of terpenoids and relative cyclic compounds using a plant pathogenic fungus. In our previous papers, we reported the biotransformation of monoterpene ketones $(+)$-camphorquinone ${ }^{1,22}$, (-)-camphorquinone ${ }^{1) .2}$, karahanaenone ${ }^{3)}$ by various fungi. Camphorquinone and karahanaenone were reduced to alcohols with high stereoselectivity by Aspergillus niger and Glomerella cingulata, respectively. In addition, biological reduction of 4methylcyclohexanone by $G$. cingulata was formed trans-alcohol as main product ${ }^{4}$. From the report of other researches, the biotransformation of 4-tertbutylcyclohexanone by Aspergillus repens MA $0197^{5)}$ Chlorella pyrenoidosa $a^{6}$ and Rabbit ${ }^{7}$ were known to give the corresponding cis- and/or transalcohols. Here we report the biological stereoselective reduction of 4-tert-butylcyclohexanone by ten kinds of anthracnose fungi.

\section{Materials and Methods}

\section{$2 \cdot 1$ Microorganism}

Glomerella cingulata, Colletotrichum fragariae,

Corresponding author: Mitsuo MiYazawA
C. lindemuthianum (C-1), C. lindemuthianum $(\mathrm{C}-$ 3), C. lindemuthianum(C-13) and C. lagenarium used in this study were obtained from Gifu University, where it was prepared by Prof. Dr M. Hyakumachi. C. atramentarium MAFF 712102, C. trifolii MAFF 305389, C. dematium MAFF 410046 and $C$. graminicola MAFF 305460 were purchased from the Genetic Resources Center National Institute of Agrobiological Resources Ministry of Agriculture, Forestry and Fisheries(MAFF), Japan.

\section{$2 \cdot 2$ Culture conditions}

Spores of microorganisms which had been preserved at low temp. were inoculated into sterilized culture media : $1.5 \%(\mathrm{w} / \mathrm{v})$ saccharose, $1.5 \%(\mathrm{w} / \mathrm{v})$ glucose, $0.5 \%(\mathrm{w} / \mathrm{v})$ polypeptone, $0.1 \%(\mathrm{w} / \mathrm{v}) \mathrm{K}_{2} \mathrm{HPO}_{4}, 0.05 \%(\mathrm{w} / \mathrm{v}) \mathrm{KCl}, 0.05 \%(\mathrm{w} / \mathrm{v})$ $\mathrm{MgSO}_{4} \cdot 7 \mathrm{H}_{2} \mathrm{O}, 0.001 \%(\mathrm{w} / \mathrm{v}) \quad \mathrm{FeSO}_{4} \cdot 7 \mathrm{H}_{2} \mathrm{O}$ and distilled water, $\mathrm{pH} 7.2$ in an Erlenmeyer flask which was autoclaved at $121^{\circ} \mathrm{C}$ for $15 \mathrm{~min}$. and shaken at $27^{\circ} \mathrm{C}$ for $3 \mathrm{~d}$. The mycelia were transplanted in a $1 \mathrm{~L}$ stirred fermenter containing $800 \mathrm{ml}$ of a medium. Cultivation was carried out at $27^{\circ} \mathrm{C}$ with stirring for $3 \mathrm{~d}$ with aeration. After the growth of $G$. cingulata, the 4-tert-butylcyclohexanone $(200 \mathrm{mg}$ ) was added directly into the medium and cultivated for $7 \mathrm{~d}$. 


\section{$2 \cdot 3$ Time-course experiment}

Everyday, $10 \mathrm{ml}$ of the culture medium was removed and saturated with sodium chloride. Then, the culture medium was extracted with dichloromethane $(3 \mathrm{ml})$. The extract was analyzed by GC. The ratio between the substrate and metabolic products were determined on the basis of the peak area of GC and are shown in Figs.1 3 , respectively.

\section{$\mathbf{2 \cdot 4}$ Isolation of metabolites}

After incubation time of $7 \mathrm{~d}$, culture medium and mycelia were separated by filtration, and the filtrate $(730 \mathrm{ml})$ was saturated with sodium chloride and then extracted with dichloromethane $(200 \mathrm{ml})$. The extracts were evaporated and analyzed by GC and GC-MS (see below). The products were identified by comparison of retention times (cisalcohol ; $22.5 \mathrm{~min}$, trans-alcohol ; $23.8 \mathrm{~min}$ ) and mass spectra ${ }^{6}$ with those of authentic specimens.

The extracts were subjected to chromatography on Si-60 columns with a hexane / diethyl ether gradient(from $99: 1$ to $8: 2$ ) to give the products : C. atramentarium MAFF 712102(1-1 ; $21 \mathrm{mg}, 1-2$; $112 \mathrm{mg})$, C. dematium MAFF $410046(1-1 ; 103$ $\mathrm{mg}, 1-2 ; 60 \mathrm{mg}), C$. fragariae $(1-1 ; 27 \mathrm{mg}, 1-2$; $135 \mathrm{mg})$, C. graminicola MAFF $305460(1-1 ; 28$ $\mathrm{mg}, \mathbf{1 - 2} ; 112 \mathrm{mg})$, C. lagenarium $(\mathbf{1 - 1} ; 20 \mathrm{mg}, \mathbf{1 - 2}$ ; $120 \mathrm{mg})$, C. lindemuthianum (C-1) (1-1; $120 \mathrm{mg}$, $1-2 ; 40 \mathrm{mg}), C$. lindemuthianum (C-3) $(1-1 ; 60$ $\mathrm{mg}, 1-2 ; 121 \mathrm{mg})$, C. lindemuthianum (C-13) (1-1 ; $24 \mathrm{mg}, 1-2 ; 72 \mathrm{mg})$, C. trifolii MAFF 305389 (1-1; $56 \mathrm{mg}, 1-2 ; 28 \mathrm{mg})$, G. cingulata $(1-1 ; 54 \mathrm{mg}, 1-2$; $27 \mathrm{mg}$ ) respectively.

\subsection{GC conditions}

GC was carried out using a Hewlett Packard 5890 equipped with a flame ionization detector on a capillary column (TC-WAX FFS Fused Silica $0.25 \mathrm{~mm}$ i.d. $\mathrm{X} 60 \mathrm{~m})$. The column temperature was programmed from $80^{\circ} \mathrm{C}$ to $210^{\circ} \mathrm{C}$ at the rate of $4^{\circ} \mathrm{C} / \mathrm{min}$ and then held at $210^{\circ} \mathrm{C}$. The injector and detector temperatures were $240^{\circ} \mathrm{C}$. The flow rate of carrier gas(He) was $0.6 \mathrm{ml} / \mathrm{min}$.

\section{$2 \cdot 6$ GC-MS conditions}

GC-MS was carried out with a Hewlett Packard 5972. GC conditions were the same as previously described(2.5 GC conditions). The flow rate of the carrier gas $(\mathrm{He})$ was $0.6 \mathrm{ml} / \mathrm{min}$. The detector interface temperature was set $280^{\circ} \mathrm{C}$, with the actual temperature in the MS source reaching approximately $180^{\circ} \mathrm{C}$ and the ionization voltage 70
$\mathrm{eV}$.

\subsection{Chemicals}

4-tert-butylcyclohexanone(1) and a mixture of cis- and trans-4-tert-butylcyclohexanol were purchased from Tokyo Kasei Kogyo Co., Ltd.

\section{Results and Discussion}

To clarify the time course of the microbial transformation of 4-tert-butylcyclohexanone(1) by ten fungi the analytical amount of 1 was incubated with fungi for $7 \mathrm{~d}$, respectively. 4-tertButylcyclohexanone(1) was used as starting material, and the medium was analyzed at one day intervals for $7 \mathrm{~d}$. After one day of cultivating the biological reduction was detectable. The mass and GC data of the products were indentical to those of authentic 4-tert-butylcyclohexanols, the predominant isomer being trans-4-tert-butylcyclohexanol(1-1). The compound 1 was reduced the corresponding cis- and trans-alcohol (Scheme 1). Other product was not detected by GC analysis.

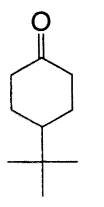

(1)

\section{microorganisms}

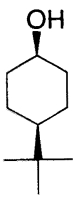

$(1-1)$

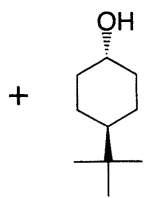

(1-2)
Scheme 1 The Reduction of 4-tert-butylcyclohexanone (1).

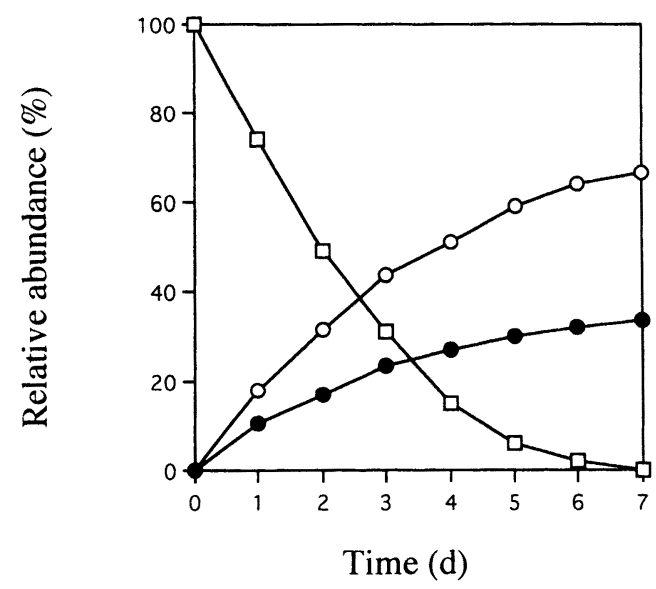

Fig.1 Time Course of Metabolic Products of 4-tertbutylcyclohexanone (1) by $C$. lindemuthianum (C-3).

$\square:$ 4-tert-butylcyclohexanone(1); : cis-4-tertbutylcyclohexanol(1-1); $\bigcirc$ : trans-4-tert-butylcyclohexanol (1-2). 
The time course of 4-tert-butylcyclohexanone by C. lindemuthianum (C-3) were shown Fig.1. The compound 1 had completely disappeared after $7 \mathrm{~d}$ incubation period and the corresponding cisalcohol(33.3\%) and trans-alcohol(66.7\%) were generated. The ratio of cis- and trans-alcohol was $1.0: 2.0$. The compound 1 was transformed to trans-4-tert-butylcyclohexanol as the major product at the end of $7 \mathrm{~d}$. In the case of $C$. lagenarium, the ratio of cis- and trans-alcohol was $1.0: 6.0$ after $7 \mathrm{~d}$ incubation period (Fig:2). On the other hand,

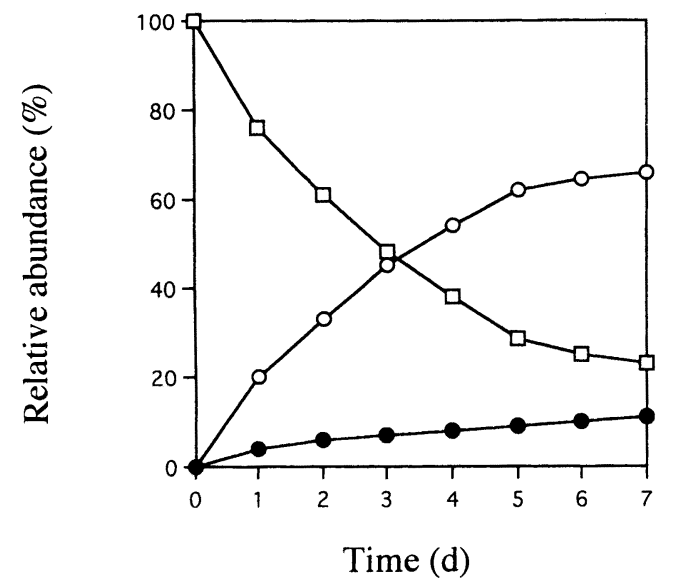

Fig.2 Time Course of Metabolic Products of 4-tertbutylcyclohexanone (1) by $C$. lagenarium. $\square:$ 4-tert-butylcyclohexanone(1); : cis-4-tertbutylcyclohexanol(1-1); $\bigcirc$ :trans-4-tert-butylcyclohexanol (1-2). in the case of Glomerella cingulata, $C$. lindemuthianum(C-1), C. trifolii MAFF 305389 and $C$. dematium MAFF 410046, the microbiological reduction of 1 was metabolized mainly cisalcohol. As shown in Fig.3, the main product was cis-alcohol $(56.8 \%)$ by using $C$. dematium MAFF 410046. In the case of four fungi ( $G$. cingulata, $C$. lindemuthianum(C-1), C. trifolii MAFF 305389 and $C$. dematium MAFF 410046), the thermodynamically unstable isomer (cis-form) was produced rather than the stable isomer (trans-form).

Table 1 The Ratio of cis/trans-cyclohexanols after 7 Days Cultivation of Cyclohexanols with 10 Fungi.

\begin{tabular}{lcccc}
\hline & & & & \\
\multicolumn{1}{c}{ microorganisms } & $(\%)$ & $(\mathbf{1 - 1})$ & $:$ & $(\mathbf{1 - 2})$ \\
\hline Colletotrichum atramentarium MAFF 712102 & 74.2 & 1.0 & $:$ & 5.3 \\
Colletotrichum dematium MAFF 410046 & 90.2 & 1.7 & $:$ & 1.0 \\
Colletotrichum fragariae & 91.5 & 1.0 & $:$ & 5.0 \\
Colletotrichum graminicola MAFF 305460 & 78.4 & 1.0 & $:$ & 4.0 \\
Colletotrichum lagenarium & 76.9 & 1.0 & $:$ & 6.0 \\
Colletotrichum lindemuthianum (C-1) & 66.0 & 2.0 & $:$ & 1.0 \\
Colletotrichum lindemuthianum (C-3) & 100 & 1.0 & $:$ & 2.0 \\
Colletotrichum lindemuthianum (C-13) & 53.8 & 1.0 & $:$ & 3.0 \\
Colletotrichum trifolii MAFF 305389 & 46.8 & 2.0 & $:$ & 1.0 \\
Glomerella cingulata & 45.6 & 2.0 & $:$ & 1.0 \\
\hline
\end{tabular}


The ketone:alcohol ratio after $7 \mathrm{~d}$ microbiological reduction of 4-tert-butylcyclohexanone also the cis : trans ratios of the 4-tert-butylcyclohexanols with ten fungi are shown in Table 1. The cyclic ketone was reduced by all of microorganisms, the ratio of cis : trans-alcohol was different by each fungus. The results(Table 1) indicate that the reduction of 1 by $C$. lagenarium produced transalcohol(1-2) with stereoselectivity, and compares favorably with previously reported biotransformation of 1 by algal ; Chlorella pyrenoidosa ${ }^{6}$. Our findings are different from those of Doi $e t a l^{5}$, in which $A$. repens MA 0197 produced almost exclusively cis-alcohol isomer from 4-tert-butylcyclohexanone.

Thus, the biotransformation of $\mathbf{1}$ was formed mainly trans-form(1-2) by $C$. lagenarium, $C$. atramentarium MAFF 712102, $C$. fragariae, $C$. graminicola MAFF 305460, C. lindemuthianum(C3 ) and $C$. lindemuthianum(C-13). A noteworthy feature of stereoselective reductions were the produce of $c i s$-alcohol(1-1) as main product by $G$. cingulata, C. lindemuthianum(C-1), C. trifolii MAFF 305389 and $C$. dematium MAFF 410046 at the end of 7 days. All of the above results suggested that ten species of anthracnose fungi were classified two groups of cis-formation type and trans-formation type.

(Received Oct. 23, 1998 ; Accepted Dec. 25, 1998)

\section{References}

1) M. Miyazawa, M. Nobata, M. Hyakumachi, H. Kameoka, Phytochemistry, 39, 569 (1995).

2) M. Miyazawa, M. Nobata, M. Hyakumachi, H. Kameoka, Phytochemistry, 44, 79 (1996).

3) M. Miyazawa, K. Tsuruno, H. Kameoka, Tetrahedron Asymmetry, 6, 2121 (1995).

4) M. Miyazawa, S. Okamura, H. Kameoka, J. Chem. Tech. Biotechnol., 65, 171 (1996).

5) N. Doi, M. Matsui, Y. Shuto, Y. Kinoshita, Agric. Biol. Chem., 54, 1177 (1990).

6) F. Yoshizako, A. Nishimura, M. Chubachi, $J$. Ferment. Bioneg., 77, 144 (1994).

7) T.H. Elliott, R.C.C. Tao, R.T. Williams, Biochem. J., 95, 59 (1965). 


\section{日本油化学会誌本号掲載 論文要旨}

\section{[総説］リン脂質ヒドロペルオキシドグルタチオンペル オキシダーゼ (PHGPx)の構造と機能}

今井 浩孝・中川 靖一

北里大学薬学部衛生化学 (厂108-8641 東京都港区白金 5-9-1)

リン脂質ヒドロペルオキシドグルタチオンペルオキシダーゼ (PHGPx) は生体膜に生じた過酸化反応の一次生 成物であるリン脂質ヒドロペルオキシドを直接還元する細胞内の唯一の抗酸化酵素である。本酵素は活性中心に特 殊アミノ酸であるセレノシステインを有するユニークなセレノタンパク質である。本酵素にはミトコンドリアへの ターゲットシグナルを有するミトコンドリア型 PHGPx と核や細胞質などに存在する非ミトコンドリア型 PHGPx が存在し，この二つの PHGPx の転写開始点が異なることから，転写レベルで制御されている。PHGPx 高 発現株を用いた解析から，PHGPx は生体膜に生成する過酸化脂質を消去するほか，核においては炎症性脂質义 ディエーターであるロイコトリエン産生の調節に関与し、ミトコンドリアにおいてはミトコンドリア電子伝達系か ら発生する活性酸素、過酸化脂質を消去し，細胞死の抑制に重要な役割を担っていることが明らかとなってきた。 また最近，活性酸素 (ROS) が転写因子 $\mathrm{NFKB}$ 活性化などのシグナル伝達経路に関与していることが報告された が，PHGPx は血管内皮細胞においてインターロイキン 1 による NFKB の活性化を抑制することが報告された。 本稿では新たに明らかになってきたPHGPx の細胞内における生理機能を解説する。

(連絡者：今井浩孝）Vol. 48, No. 4, 293 (1999)

\section{[報文］炭疽病菌による 4-tert-butylcyclohexanone の立体選択的還元}

岡村 茂昭・宮澤 三雄・亀岡 弘 近畿大学理工学部応用化学科（宁577-8502 大阪府東大阪市小若江 3-4-1)

テルペノイドおよびそれらの関連化合物の衛生物変換に関する研究の一環として, 10 種の植物病原菌（炭疽 病）を生体触媒として用い，4-tert-butylcyclohexanone の変換を行った。その結果，基質はケトン基の還元反 応が進行し，それぞれ対応する cis および trans-alcohol 体に変換され，菌種により主要変換物は異なっていた。 Colletotrichum lagenarium, C. atramentarium MAFF 712102, C. fragariae, C. graminicola MAFF 305460, C. lindemuthianum (C-3) および C. lindemuthianum (C-13)では trans-4-tert-butylcyclohexanol を主要変換物として生成するのに対し, Glomerella cingulata, C. lindemuthianum (C-1), C. trifolii MAFF 305389 および C. dematium MAFF 410046 では cis-alcohol 体を主要変換物として立体選択的に生成すること を明らかにした。

（連絡者 : 宮澤三雄）Vol. 48, No. 4, 303 (1999) 